\title{
THE RENOUF PAPERS: AN AMERICAN ACADEMIC IN CHINA, 1903-1910
}

\author{
BY SUSAN MORRISON YEN
}

Mrs. Yen is a graduate student in history at Rutgers University

$\mathbf{R}$

ECENTLY donated to the Special Collections of Alexander Library, the Renouf papers provide a first-hand account of the intellectual earthquake China experienced around the turn of this century. Following the debacle of the Boxer Rebellion in I900, the Ch'ing Dynasty's last decade witnessed a greatly increased penetration of Western thought and methods into China. The Manchu regime's allegiance to the traditional patterns to which it had clung for so long was finally broken in the face of overwhelming Western technological superiority. Instead, a policy of selective absorption and adaptation of things Western was adopted.

The primary aim of university education in this period was technological Westernization and the upgrading of future bureaucrats to enlighten the masses and guide China's future. Concomitantly, Western knowledge was to be used as a means of preserving Chinese moral values.

With such an object in mind, various schools and programs introducing Western subjects were started in China. In view of the subsequent intellectual response to the West and the rigors of modernization it is of some interest to know exactly what was being taught in these programs, how it was presented and received, and something about the aspirations and orientations of those Western scholars who undertook the challenge of condensing and transmitting the quite alien complex of experience and thought that was the West-a far from monolithic or easily intelligible corpus.

Vincent Adams Renouf was an American who served as professor of first chemistry and then history and political economics at the Imperial Peiyang University in Tientsin from I905 until I910. In many respects Professor Renouf can fairly be regarded as typical if somewhat more influential than his pioneering peers by virtue of his widely accepted textbook Outlines of History for Eastern Students, first published in I 908.

A selected chronological collection of papers concerning Renouf's involvement with the Far East begins with two papers he wrote as 
a senior at Johns Hopkins University in I 898. Titled the "History of China and Japan" and "The New Japan," they pay particular attention to the political and economic effects of modernization and industrialization, as well as the cultural heritage, expressing general admiration for recent Japanese advances. Schoolboy essays, they tend to be moralistic, poetic, and childishly simplistic, from the typicalJapanese steal Western ideas, their food is not filling-to the possibly original but absurd notion of the effect of frequent earthquakes on Japanese architecture, economy, and values. Their author is nevertheless politically acute. He understands the reasons for past Japanese aloofness to missionary Christianity, and perceives some of the underlying economic and political tensions that will loom large in the future of the region ("There will be many a nut to crack").

On April 24, I90I, then twenty-five years of age, Vincent Adams Renouf wrote an autobiographical letter of personal application to Sir Robert Hart, Inspector General of Chinese Imperial Maritime Customs, for an appointment to the Chinese Customs Service. A folder of assorted personal letters from his collected papers yields the following additional biographical information.

Of old New England stock, Renouf was born in Germany in January 1876 , where he graduated from high school. After majoring in economics and history, Renouf graduated with honors in 1898 from Johns Hopkins University, where his father was professor of chemistry. He attended Harvard Graduate School in I899-I900 for work in history, but decided to take a position with the Roxbury Latin School teaching German and history. At this point in I9OI he found himself possessed of an international family and personal background, tied only by friendship to the United States, master of three languages, and apparently eager for further travels and challenges.

On the 8th of June he was informed that his "name has been noted, but that at present, there were no vacancies." However, by September 2nd he was appointed to the post of Fourth Assistant B in the Chinese Imperial Maritime Customs Service, with a salary of Ioo Haikuan taels (or approximately U.S. \$75.00) per month. In January of 1903 Renouf was offered a professorship at Tientsin University at 300 Hongping taels (or U.S. \$2 I9.00) per month, which he accepted the next day. He was employed there from the end of March I 903 as Professor of Chemistry. Three years later he was employed as a Professor of History (with an extra 50 taels, 
or U.S. $\$ 32.50$, per month). Chinese universities were anxious to utilize any and every area of Western expertise, albeit divergent ones in one individual. In late 1908 he was formally retired, with one year's pay of $2,005.20$ Shanghai taels (or U.S. $\$ 1,283.23$ ) from the Customs Service. This was apparently munificent enough to allow him to expand and reorganize his house the following year. He died of typhus on the $4^{\text {th }}$ of May Igro. His wife, the former Baroness Von Pechmann, and their children left China later that year for her native home in Munich, Germany.

Upon his arrival in China, Vincent Renouf plunged into the study of the Chinese language. Chats in Chinese-A translation of the "T'an Lun Hsin Pien" (I9Or) by C. H. Brewitt-Taylor of the Chinese Imperial Maritime Customs is a well-used book in Renouf's collection that was conceivably a basic text at this time. Translated from a book of colloquial Chinese, the exercises are styled as conversations between a Chinese and a visiting Japanese and provide many interesting glimpses into contemporary Chinese life and opinions. For example, Section XCIV on page Iog sets out the prevailing. naïve view on Westernization, generally approving as harmless selected technological adaptations such as railways and steamships.

Following his appointment in $\mathrm{I} 903$ as a professor at Peiyang University, the new chemistry teacher made a handwritten report of post-Boxer developments in Tientsin, concentrating particularly on the economic effects. The uprising he describes as "a passing sickness, followed by redoubled vigor." This vigor is in no small part due to the completed annexation of all waterfront properties by foreign powers, and their subsequent commercial development. The most important spur to recovery, in Renouf's estimation, is the firm reformatory decrees of the new Viceroy-later the first President of the Republic-Yuan Shih-k'ai. Yuan at this time apparently emphasized rapid modernization and an orderly population.

The benefits of a greatly enlarged volume of trade were balanced by the stability of a widely fluctuating exchange rate. This problem was in turn over-controlled by the Tientsin Provisional Government. Yuan's government was apparently full of various innovative schemes. Big increases in revenue from import duties were recorded -double that of I 899-while revenue from export duties lagged behind that of 1899 . This could be due to the effects of foreign intrusion and increased Chinese demands for foreign goods. The return of the court to Peking in I 902 was followed by increased evidence 
of a will to modernize, such as contracts for railway construction and provisions for steamship transport, which would have important economic consequences for the future.

In his first year Renouf also left an important record of his classroom techniques and material in a blue notebook containing the "Elementary General History of Industry and Commerce."-_Lectures given to the students of the Chinese Imperial University.Tientsin.-r 903." He emphasizes the use of his lectures as an exercise in English as well as the principal subject, so the language employed is simpler than the concepts presented. He also makes particular note of the need to encourage student participation, which lagged due to their lack of courage and facility in using English, and the newness of self-expression aside from memorization of the material. His initial estimation of the students was not the highest (". . . too difficult for the brain capacity of these students . .."), and he found it necessary to take into account their numerous linguistic and organizational study problems.

It is interesting to observe how much of the material Renouf faithfully passes on as the accepted wisdom is no longer held to be true. His historical approach stresses philological roots, the effects of climate and geography on human development, and approvingly notes the "Great Man" theory of historical development. Where Professor Renouf laudably tries to bring in Chinese similies to make the basically Western material more understandable to his Chinese students, in so doing his erroneous examples reveal a certain ignorance of matters Chinese.

In his history notes from I 904 Renouf uses Guizot's overly simplistic idea of single-principle civilizations to characterize various non-European histories. The contrasting dynamism of European history is attributed to conflicting principles such as Church vs. State. This reflects the vast difference in the depth of Western knowledge about their own and non-Western cultures. The most important key to success is conceived to be the ability to learn from one's neighbors (and betters), particularly if they are European or Caucasian. Thus follows an exhortation to the students of China to develop "the capacity to learn" and "to carry our studies into practice" in the patriotic service of strengthening the country.

An undated envelope of stray notes contains recommendations for revisions in the customs service admission procedure, extensive notes on Locke's Civil Government, and assorted quotes such as Charles 
Francis Adams' cautionary 'Patriotism, piety, and filial duty have nothing to do with (the study of history) - they are, indeed, mere snares and sources of delusion."

Professor Renouf's most extensive work on the subject of history is his book Outlines of General History For Eastern Students printed in July of 1908 for Macmillan and Co., Ltd. He cites the recent introduction of Western studies in Chinese schools and the new constitutional movement as revealing the need for a book of this sort. It was tested in use preparing a class of Normal Students for teachers in the Government Middle Schools of Chihli (presently Hopei) Province. The bulk of the book is devoted to Western history, from "Egypt" to "The American Countries During the I 9 th Century," with a chapter on "The Ancient Oriental Countries" and "The Transformation of the Far East."

Under techniques Renouf recommends trying to combine various non-verbal means, such as the use of pictures, with an understanding of the traditional Chinese stress on memorization, to be used particularly for dates, while underlining the need for student comprehension of the textual material as well.

Although the large sections on Western history are uncontroversial, the contemporary accepted wisdom on ethnology in his Introduction relates that Negroes are an inferior race, primarily given to serving as slaves for "the stronger and cleverer members of the higher races." The "lack of progress among Chinese and Japanese during several centuries" is due solely to "their geographical isolation from the West."

In the modern period, Renouf's account reflects the moral condemnation-and economic justification —of the Opium War, which is seen as rudely arousing "the sleeping giant" of China. The role played by the legendary "Chinese" Gordon and other European personnel figures large in his brief account of the Taiping Rebellion. On the whole, recent events are described in the same dispassionate tone as the rest of the book. His text is distinguished from its predecessors by the much larger section on oriental events.

From late 1908 comes notes from his lectures on Woodrow Wilson's The State (I 898), the principal textbook for Renouf's course on "Legal Institutions" in which Renouf combines his own racialphilological approach. Chinese social institutions are often likened to those of the Romans, i.e. just a cut above the most basic civilized level. The instructor praises tolerance, as practiced by the Germanic 
and Chinese races in religious matters, as a sign of dynamism. Episodes of intolerance in Western history are labeled as displaying a Jewish trait, thus imparting an implicit anti-Semitism. Renouf also traces a Darwinian-Spencerian conflict between weaker and stronger nations leading to the survival of the best. This philosophy was much in vogue.

For the fall term of '08 Renouf also prepared a notebook entitled Summary of and Notes on J. S. Mill's Principles of Political Economy. The professor likens the state of present day Chinese economics to that of Europe in 1766 when Adam Smith published his "Wealth of Nations." 'The course's focus on Mill, as midway between the Europe of Adam Smith and I908, presupposed "the economic life of China must in a future not far off go through the revolutions experienced in the West." This reveals both the Western confidence in its ways as trail-blazer and model, and an amazing insensitivity to the difference between European and Chinese historical circumstances. One point has not escaped his attention, as Renouf repeatedly stresses the importance of population control to China's future development.

The only papers preserved written by Chinese students are three essays comparing family conditions and the status of women in the East and the West. The students are in essential agreement as to the benefit of Western independence and self-dependence as opposed to the Chinese system of all relatives leaning on one strong member. They all condemn the low status of women in China as opposed to their relative freedom and liberation in the West, pointing out particularly the detrimental effect such oppression and stunted growth has on the mother's important role as educator of the next generation. Although in general the English struggles to express the concepts conveyed, the students write with apparent conviction and fervor. It would seem the seeds of a social revolution had been sown.

Renouf's collection also contains his note cards on filial piety and the basis of Chinese law and punishments as expressed in an imperial edict at that time. Traditional precepts are defended and justified, despite their difference with those of the West, as being best for China. This was the official line, the reiteration of the old in the face of the new challenges from students and Westernizers.

From 1908-09 comes a sheaf of letters regarding negotiations for the publication and distribution of his book, including some in- 
teresting observations by Renouf on the type and readership of books in English likely to appeal to Chinese ("What the Chinese want from the West, it seems to me, is realities rather than myth and fancy..... In a few years the number of English-reading Chinese will count over hundred thousand [sic], and it seems likely that English will play in China the same part which it already plays in Japan."). Also included are some mid-year exam questions (January I9IO) on Comparative Legal Institutions, Social Economy, and Finance, which are fairly rigorous.

Being fluent in German, Professor Renouf acquired a book on China, "Menschen Und Berge (in China)" by Von H. Steiner, printed in Munich in $\mathbf{r} 909$.

The China Philosophical Society's initial bulletin on "Organization, Provisional Constitution, and the Presidential Address" was also published in I 909, in Tientsin. This bulletin provides an example of current intellectual sympathies. Its main interest was "to promote science for the benefit of China and the Chinese." The prevailing sentiment was that China had turned a new leaf from her former conservatism and now felt "that in the struggle for existence, we must come up in line with western nations ... we must, in short, adopt or adapt western civilization in all the spheres of human activity and retain whatever is good in our own." It is also recorded that in September Professor V. A. Renouf of the Imperial Pei Yang University was to give a report, which was now postponed due to his illness.

In early I 9 Io, despite inflammatory rheumatism, Professor Renouf was able to deliver a lecture before the Society on "The Population Question in China" in which he opposed Henry George ("population cannot increase too much") in favor of Malthus and J. S. Mill. Renouf defines the population question in terms of $\frac{\mathrm{m}}{\mathrm{p}}=\frac{\text { means of subsistence }}{\text { population }}$ with $m$ dependent on "the industrial

skill of the inhabitants." He therefore points to an impending demographic disaster due to China's rapid increase in population since I 7 I I.

Renouf goes on to cite a comparison of the Chinese birth rate among all classes (six children per family) with the difference in birth rates between upper and lower classes in the West due to the former class's use of contraceptives. A rigorous Malthusian and 
Darwinian, Renouf feels that famine, disease, and rebellions are nature's inevitable attempts to balance unfettered reproduction. His conclusion: the source of much of China's ills is the debilitating strain of her over-population.

A large blue folder contains notes he submitted in March I9ro to the popular journal "Outlook" for an article. It largely duplicates and expands upon the material presented in his lecture before the China Philosophical Society. In this he stresses the importance of limiting population growth, especially among the lower classes, in order to effect progress for all. Industrialization is held to be of no benefit without such limits, considering the material basis of all progress. Under methods he advocates both abstinence and a state monopoly on artificial preventive measures, and suggests criteria for their sales. All this leads to the goal of better races, since only so many people can be provided for ("By a limitation of numbers we get a grip on our destiny.").

To augment his study on this question Renouf sent letters, one of which is preserved, to various sources such as pharmacies to ascertain the methods and availability of contraception in China. In April he wrote a letter to "The Information Bureau, The Times Book Club, London" requesting a bibliography on the subject.

A number of unfinished manuscripts remain from this time, including one for a book entitled Introduction to the Study of History, with a useful Teacher's Guide. Renouf writes for the middle and upper school level student who has a greater background in history than in English. Therefore the English is simple and constructed as a McGuffy-type Reader, while the concepts expressed are more advanced. Renouf believes that the Chinese difficulty in learning English "did more than all other causes together" in preventing the spread of Western ideas and hence fatally delayed China's modernization. Indeed, in the next several decades the translations into Chinese of standard English classics by men such as Yen Fu were to have a tremendous effect.

The book's section on race and weather is the most controversial. Due to the debilitating effects of heat and sun on "the fair-skinned and blue-eyed Germanic races ... the work in the tropics must be done by dark races." Hence, "white men can be the lords and task masters, but they can stay only for a few years at a time, and must constantly return to their native climates to recuperate ... . unless they are willing that the children should become weak." A follow- 
up examination question is "Why must light-complexioned Europeans guard themselves so carefully against the summer sun in North China?" The professor's German wife probably influenced his specific concern on the fore-going.

Sources of wars and revolutions are to be found in "the social conditions of the people" which he defines as religion, the distribution of wealth and political rights, education, and the actual relations of the government to the people. In his chapter on "How To Study History" Professor Renouf stressed the importance of understanding-rather than memorizing-what is studied, in order to develop the power of reasoning from cause to effect. The best test is therefore to repeat the lesson in one's own words, rather than word-for-word, and to stress the context. Renouf sees his book as part of "The Awakening of China," while stressing that wisdom comes not from books, which are shadows of reality, but "by observations of actual events." He encourages the use of present-day similies from observed realities for understanding past events and conditions, asks for a questioning, critcial mind, and stresses exactness at every stage.

A miscellaneous envelope contains personal letters of biographical interest through the time of his death. A review from the "Independent," a New York City paper, of August I 9 Io states the "General Outline" was "evidently written primarily for young Orientals getting their first glimpse of the rise and growth of Western civilization and its connection with their own," implying that the book lacked scholastic originality and interest for other readers. However, a review from 1922 commemorating a revised edition following the twelfth printing notes the book was "quickly adopted by schools and colleges throughout the Far East." Letters also attest to the interest of the Egyptian and Malayan Straits Settlement education authorities in revised editions of Renouf's text. The book went through twenty reprintings, including one for the Egyptians, though its use in Peiyang Imperial University was discontinued following Renouf's death.

It is hoped that the foregoing papers of a young American professor in early twentieth century China might be of some help to a scholar desiring a closer examination of this period, or of simply teaching history to foreigners, though Renouf's concerns go beyond his profession. Vincent Adams Renouf is sympathetic to his young charges and the challenges they face in trying to rapidly 
strengthen a great but failing country under tremendous pressures. He tries to ease the break with traditional patterns by pointing out similarities (occasionally overdrawn) as well as differences wherein he wishes the students to emulate the West he represents. An intelligent and fairly broad-minded man, Renouf nevertheless is a captive of his age, imparting prejudices as well as more verifiable factual developments. Concerned with China's fate in the future and bold enough to pursue his concerns, Renouf is embued with missionary-like zeal. As did his path-breaking religious counterparts, he sought to enlighten, transform, and thereby save a society that he found both admirable and deplorable, in truth more alien and complex than he realized. Harbingers of much that was to come, even Maoist pragmatism is in debt to such men from the West. 